\title{
PROCJENA I PRAĆENJE KOMUNIKACIJSKIH SPOSOBNOSTI OSOBA S TRAUMATSKIM OZLJEDAMA MOZGA
}

\author{
TATJANA PRIZL JAKOVAC ${ }^{1}$, SANJA HABUS ${ }^{2}$ \\ ${ }^{1}$ Sveučilište u Zagrebu, ERF, Odsjek za logopediju, tatjana.prizl-jakovac@vz.t-com.hr \\ ${ }^{2}$ Specijalna bolnica za medicinsku rehabilitaciju Krapinske Toplice, Odjel za rehabilitaciju kraniocerebralnih \\ bolesnika i akutnu neurologiju, sanja.habus@outlook.com
}

Primljeno: 25.9.2016.

Izvorni znanstveni rad

Prihvaćeno: 15.12.2016.

UDK: 616.83-001: 159.946.3

Sažetak: Komunikacijske su teškoće kod osoba s traumatskom ozljedom mozga različite, uzimajući u obzir rasprostranjenost ozljede, vrstu udaraca i težinu traumatskog oštećenja mozga.

Cilj ovoga rada, i u tu svrhu provedenog istraživanja, bila je procjena komunikacijskih sposobnosti osoba s traumatskim oštećenjem mozga na verbalnom, gestovnom i grafičkom modalitetu primjenom Porch indeksa komunikacijskih sposobnosti (Porch Index of Communicative Ability, PICA, B. E. Porch, 1981) prevedenog i prilagođenog hrvatskom jeziku.

Ispitivanje je provedeno na 14 ispitanika obaju spolova, u dobi od 21 do 62 godine, kroz tri vremenska razdoblja u razmaku od tri mjeseca, kako bi se pratio napredak ispitanika kroz ponovljena ispitivanja. Svi su ispitanici bili na liječenju i rehabilitaciji u Specijalnoj bolnici za medicinsku rehabilitaciju u Krapinskim Toplicama.

Prikupljeni su podatci obrađeni univarijantno i multivarijntno. Korišten je Friedmanov neparametrijski test za testiranje značajnosti razlika aritmetičkih sredina malih zavisnih uzoraka. Za analizu sustava varijabli kvalitativnih i kvantitativnih promjena jednog uzorka u dvije vremenske točke korišten je program PROM (Nikolić, 1997).

Dobiveni rezultati ukazuju na najmanji stupanj oporavka u verbalnom modalitetu. Gestovni modalitet je značajno oštećen u početnim ispitivanjima, ali se pod utjecajem terapije brže oporavlja. Grafički modalitet opisuju najlošiji rezultati zbog pareza ili plegija ekstremiteta. Rezultati ukazuju i na važnost zastupljenosti određenog modaliteta u ranoj rehabilitaciji komunikacijskih poteškoća nakon ozljede mozga.

Ključne riječi: traumatsko oštećenje mozga, komunikacijske teškoće, Porch indeks komunikacijskih sposobnosti.

\section{UVOD}

Ozljede glave i mozga vrlo su česte. Njihov glavni uzrok prometne su nesreće uvjetovane suvremenim i užurbanim načinom života. Učestalost traumatskih ozljeda najveća je kod mladih osoba muškog spola, u dobi između 15 i 24 godina (McDonald, S., Togher, L., Code, C. (1999). Prometne nesreće uzrok su oko $50 \%$ svih ozljeda i najčešće su povezane s teškim ozljedama. Slijede padovi i napadi s po $20 \%$, dok ostatak čine sportske ozljede i ostali uzroci. (Ylvisaker, M., Szekeeres, SH. F., Feeney, T., 2001).

Traumatsko oštećenje mozga nastaje kada neka vanjska sila djeluje na glavu dovoljno jako da se mozak pomakne unutar lubanje ili dolazi do frakture lubanjskih kostiju, čime se mozak direktno oštećuje (Graham i sur, 2000.). Ovakve se vrste oštećenja događaju kod prometnih nesreća, padova i fizičkog nasilja. Hedge (2006) posljedice traumatskih ozljeda glave dijeli na bihevioralne, kognitivno-komunikacijske i tjelesne.

Komunikacijski problemi kao posljedica traumatskog oštećenja mozga ovise o raznim čimbenicima, uključujući osobnost pojedinca, sposobnosti prije ozljede te težinu i stupanj oštećenja mozga. Zabilježeno je da se jezične funkcije nakon traumatskih oštećenja mozga oporavljaju na razini ispod rečenične, ali se osobe s traumatskim oštećenjem mozga ne snalaze na konverzacijskoj razini 
(Adamovich, 2001). Govorna produkcija osoba s traumatskim oštećenjem mozga je usporena, teško ili potpuno nerazumljiva ako su zahvaćena područja mozga koja kontroliraju mišićnu aktivnost govornog mehanizma, pa se najčešće radi o dizartričnom govoru (Yorkston i sur. 1981). Uz dizartriju česte su i smetnje gutanja i apraksija (Davis, 2007, Halpern i Goldfarb 2012.). Jedan od najkarakterističnijih simptoma komunikacijskih poteškoća nakon traumatskog oštećenja mozga jest teškoća imenovanja. Učestalost afazije kod osoba s traumatskim oštećenjem mozga kreće se između 2-30\% ovisno o autorima koji prezentiraju podatke (Heilman, Safran \& Geschwind, 1971; Sarno, 1980, 1984, 1988; Sarno, Buonaguo \& Levita, 1986, prema McDonald, S., Togher, L., Code, C. (1999) i Ylvisaker, M., Szekeeres, SH. F., Feeney, T., 2001). Najučestalija vrsta afazije, ako se ona uopće javi, kod odraslih osoba s traumatskim oštećenjem mozga je anomija (prema McDonald, S., Togher, L., Code, C. 1999). Kod osoba s traumatskim oštećenjem mozga u znatnoj su mjeri prisutni pragmatički problemi. Iako su njihove govorne i jezične vještine očuvane, vrlo često komunikacija osoba s traumatskim ozljedama mozga nije učinkovita.

Smatra se da su komunikacijski problemi kod osoba s traumatskim oštećenjima mozga prisutni zbog kognitivnih nedostataka što uključuje poremećaje pažnje, sekvencioniranja, pamćenja i kategoriziranja. Osobe s traumatskim oštećenjem mozga često su zbunjene i dezorijentirane što utječe i na njihovu komunikaciju (Murdoch, B. E. and Theodoros. D. G., 2000). Poznato je da komunikacijski problemi povezani s traumatskim oštećenjima mozga nisu uobičajeni oblici afazija niti njima slični (Ylvisaker, M., Szekeeres, SH. F., Feeney, T., 2001).

\section{PROBLEM I CILJ ISTRAŽIVANJA}

Kognitivno-komunikacijske teškoće možemo promatrati kroz jezične i govorne teškoće. Jezične teškoće izražavaju se kroz sve jezične sastavnice: leksik, semantiku, sintaksu i pragmatiku. Govorne teškoće najčešće su dizartrija koja predstavlja dugotrajan problem u komunikaciji, te disfonije i afonije. Teškoće čitanja i pisanja prisutne su od loše grafomotorike do zamjena i izostavljanja grafema.

Osnovni je cilj rada bio utvrditi stupanj komunikacijskog poremećaja nakon traumatskog oštećenja mozga kroz zadatke predviđene mjernim instrumentom (Porch Index of Communicative Ability, PICA, B.E.Porch, 1981) te pratiti promjene na verbalnom, gestovnom i grafičkom modalitetu kroz tri mjerenja u razmacima od po tri mjeseca.

\section{HIPOTEZA ISTRAŽIVANJA}

U skladu s ciljevima postavljena je osnovna hipoteza:

$H$ 1: Postoji statistički značajna razlika na varijablama verbalnog, gestovnog i grafičkog modaliteta s obzirom na slijed ispitivanja (prvo, drugo i treće mjerenje) kod osoba $\mathrm{s}$ traumatskim oštećenjem mozga.

\section{METODE RADA}

\subsection{Uzorak ispitanika}

Ispitivanjem je obuhvaćeno 14 ispitanika: 6 žena i 8 muškaraca, u dobi od 21 do 62 godine. Prema neurološkim nalazima, svi su ispitanici imali traumatsko oštećenje mozga, bili su u svjesnom stanju i uključeni u kontinuiranu, svakodnevnu logopedsku terapiju na Odjelu za rehabilitaciju kraniocerebralnih bolesnika i akutnu neurologiju u Specijalnoj bolnici za medicinsku rehabilitaciju Krapinske Toplice (Tablica 1).

\subsection{Uzorak varijabli}

Varijable su preuzete iz Porch indeksa komunikacijskih sposobnosti (Porch Index of Communicative Ability, PICA, Porch, 1981), namijenjenom osobama nakon oštećenja mozga. Test je preveden i prilagođen hrvatskom jeziku (T. Prizl Jakovac, Odsjek za logopediju, Edukacijsko-rehabilitacijski fakultet). Ukupno je primijenjeno 18 varijabli koje su podijeljene u tri modaliteta: Verbalni modalitet čine četiri varijable, gestovni modalitet čini osam varijabli i grafički modalitet čini šest varijabli (Tablica 2). Kroz uporabu testa ispitivač dobiva informacije o općim i specifičnim razinama sposobnosti produkcije te izvodi zaključke o preostalim mogućnostima i integracijskoj sposobnosti ispitanika.

Ispitanikovi odgovori boduju se kroz multidimenzionalni sustav bodovanja, tako da se bodovi upisuju u obrazac. Po završetku testiranja bodovi 
Tablica 1. Podatci o ispitanicima

\begin{tabular}{|l|l|c|c|l|}
\hline & INICIJALI & SPOL & GODINA ROĐENJA & DIJAGNOZA \\
\hline 1. & A. E. P. & $\check{Z}$ & 1950. & Difuzno aksonsko oštećenje \\
\hline 2. & J. M. & $\check{Z}$ & 1988. & Contusio cerebri \\
\hline 3. & A. B. & M & 1989. & Intraventrikularno krvarenje \\
\hline 4. & D. P. & $\check{Z}$ & 1991. & Difuzno aksonsko oštećenje \\
\hline 5. & D. P. & M & 1984. & Difuzno aksonsko oštećenje \\
\hline 6. & N. M. & M & 1982. & Contusio cerebri \\
\hline 7. & H. S. & M & 1987. & Subd.hematom,edem cerebri \\
\hline 8. & A. D. & M & 1970. & Contusio cerebri \\
\hline 9. & D. S. & M & 1979. & Fract.cranii \\
\hline 10. & A. Č. & M & 1961. & Cont.capit.cerebri \\
\hline 11. & Đ. V. & $\check{Z}$ & 1956. & Contusio cerebri \\
\hline 12. & P. B. & $\check{Z}$ & 1990. & Contusio cerebri \\
\hline 13. & T. H. & M & 1950. & Contusio capitis \\
\hline 14. & M. D. & M & 1976. & Contusio cerebri \\
\hline
\end{tabular}

Tablica 2. Modaliteti Porch indeksa

\begin{tabular}{|c|c|}
\hline MODALITETI & KRATICE \\
\hline \multicolumn{2}{|l|}{ 1. Verbalni modalitet } \\
\hline - opisivanje funkcije predmeta & (VER 1) \\
\hline - imenovanje predmeta & (VER 2) \\
\hline - dopunjavanje rečenica & (VER 3) \\
\hline - imitiranje naziva predmeta & (VER 4) \\
\hline \multicolumn{2}{|l|}{ 2. Gestovni modalitet } \\
\hline - demonstracija funkcije predmeta kroz pantomimu & (PAN 1, PAN 2) \\
\hline - čitanje uputa na karticama i smještanje kartica prema uputi & (ČIT 1) \\
\hline - pokazivanje predmeta na temelju verbalno zadane funkcije predmeta & (AUD 1) \\
\hline - čitanje naziva predmeta na kartici i smještanje kartice prema uputi uputi & (ČIT 2) \\
\hline - povezivanje slike predmeta na temelju verbalno zadanog naziva predmeta $(\mathrm{X})$ & (AUD 2) \\
\hline - povezivanje slika predmeta s predmetima & (VIZ 1) \\
\hline - spajanje istih predmeta & (VIZ 2) \\
\hline \multicolumn{2}{|l|}{ 3. Grafički modalitet } \\
\hline - pisanje rečenice o funkciji predmeta & (PIS A) \\
\hline - pisanje naziva predmeta & (PIS B) \\
\hline - pisanje naziva predmeta nakon što ga ispitivač izgovori & (PIS C) \\
\hline - pisanje naziva predmeta nakon sricanja ispitivača & (PIS D) \\
\hline - kopiranje naziva predmeta & (KOP A) \\
\hline - kopiranje geometrijskih oblika & (KOP B) \\
\hline
\end{tabular}

se subtestova skupljaju i izračunava se verbalna, gestovna i grafička razina te opća komunikacijska razina. Porch indeks komunikacijskih sposobnosti omogućuje kvantitativnu procjenu komunikacijskih poremećaja ljestvicom od 1 do 16 bodova.

\subsection{Način prikupljanja podataka}

Istraživanje je provedeno u razmaku od tri mjeseca između svakog mjerenja. Provođeno je prema standardnom redoslijedu Formata testa koji sadrži osnovne podatke o ispitaniku, njegovom zdravstvenom stanju, uvjetima testiranja te vremenu koje je bilo potrebno da ispitanik riješi cijeli test.

Nakon testiranja izračunavaju se i upisuju prosječni rezultati, postotci i varijabilnosti podtestova svakog modaliteta. Na dnu obrasca se upisuju bodovi i postotci za sva tri modaliteta, devet najvi- 
ših i devet najnižih prosjeka podtestova, prognoza u postotcima i cilj. U obrazac za rangirani sažetak odgovora se ucrtavaju rezultati podtestova koji su složeni prema težini koju definira prosjek odabranog uzorka ispitanika.

Porch, (1981) objašnjava da mozak ostvaruje komunikacijske procese kroz tri ulazna modaliteta: vizualni, auditivni i taktilni. Prijelazni stadij integracije uspoređuje i pohranjuje informacije. Izlazne informacije očituju se kroz gestovni, verbalni i grafički modalitet. Ulazni procesi uključuju recepciju, percepciju i asocijaciju, a izlazni konceptualizaciju, formulaciju i ekspresiju.

\subsection{Metode obrade podataka}

Podatci su obrađeni primjenom programa SPSS za operativni sustav Windows. Korištena su dva načina obrade podataka: Univarijantni statistički postupk Friedmanovim neparametrijskim testom za testiranje statistički značajnih razlika aritmetičkih sredina malih zavisnih uzoraka i Multivarijantni statistički postupak Prom (Nikolić, 1997) za analizu sustava varijabli kvalitativnih i kvantitativnih promjena jednog uzorka u dvije vremenske točke (za male uzorke).

\section{REZULTATI I RASPRAVA}

\subsection{Prikupljeni podatci}

Za sve varijable izračunani su osnovni statistički pokazatelji: aritmetička sredina, standardna devijacija, te minimalni i maksimalni rezultati koji su prikazani u Tablici 3.

\subsection{Analiza razlika s obzirom na slijed mjerenja}

Da bismo utvrdili postoji li statistički značajan oporavak komunikacijskih sposobnosti ispitanika tijekom mjerenja u tri vremenske točke, najprije smo analizirali rezultate svih parova mjerenja, $i$ to za svaki skup varijabli komunikacijskih modaliteta zasebno. Za ispitivanje kvantitativnih razlika između pojedinih mjerenja korišten je program PROM (Nikolić, 1997) za analiza kvalitativnih i kvantitativnih promjena jednog uzorka ispitanika opisanog skupom varijabli u dvije vremenske točke.

Vidljivo je (Tablica 3) da se ispitanici tijekom mjerenja u tri vremenske točke nisu jednako oporavljali u komunikacijskim sposobnostima. Stoga je bilo potrebno ispitati statističku značajnosti tih razlika.

Tablica 3. Osnovni statistički pokazatelji primijenjenih varijabli

\begin{tabular}{|c|c|c|c|c|c|c|c|c|c|c|c|c|c|c|c|}
\hline & \multicolumn{5}{|c|}{ 1. MJERENJE } & \multicolumn{5}{|c|}{ 2. MJERENJE } & \multicolumn{5}{|c|}{ 3. MJERENJE } \\
\hline Varijabla & $\mathbf{N}$ & Min. & Max. & A.S. & S.D. & $\mathbf{N}$ & Min. & Max. & A.S. & S.D. & $\mathbf{N}$ & Min. & Max. & A.S. & S.D. \\
\hline VER1 & 15 & 3,0 & 15,0 & 11,69 & 2,89 & 15 & 4,3 & 15,0 & 12,73 & 2,57 & 5 & 5,0 & 14,0 & 12,20 & 4,02 \\
\hline VER2 & 15 & 6,0 & 15,0 & 13,14 & 2,35 & 15 & 2,3 & 15,0 & 12,65 & 3,95 & 5 & 11,6 & 14,0 & 13,48 & 1,05 \\
\hline VER3 & 15 & 4,2 & 15,0 & 12,33 & 2,66 & 15 & 4,0 & 15,0 & 12,05 & 3,04 & 5 & 10,5 & 14,0 & 12,50 & 1,50 \\
\hline VER4 & 15 & 11,7 & 15,0 & 13,93 & 1,18 & 15 & 11,6 & 15,0 & 13,63 & 1,35 & 5 & 6,9 & 15,0 & 13,32 & 3,59 \\
\hline PAN1 & 15 & 2,0 & 15,0 & 12,01 & 3,67 & 15 & 1,0 & 15,0 & 12,51 & 4,56 & 5 & 7,4 & 15,0 & 12,88 & 3,09 \\
\hline PAN2 & 15 & 2,0 & 15,0 & 12,03 & 3,19 & 15 & 2,5 & 15,0 & 12,69 & 3,19 & 5 & 10,0 & 15,0 & 13,40 & 1,95 \\
\hline CIT1 & 15 & 1,0 & 15,0 & 11,70 & 4,67 & 15 & 1,0 & 15,0 & 12,57 & 4,43 & 5 & 6,8 & 14,4 & 12,64 & 3,27 \\
\hline CIT2 & 15 & 1,5 & 15,0 & 10,76 & 4,24 & 15 & 2,0 & 15,0 & 12,32 & 3,17 & 5 & 5,9 & 15,0 & 12,28 & 3,84 \\
\hline AUD1 & 15 & 3,0 & 15,0 & 12,93 & 3,24 & 15 & 1,5 & 15,0 & 13,00 & 3,95 & 5 & 12,4 & 15,0 & 13,88 & 0,93 \\
\hline AUD2 & 15 & 6,3 & 15,0 & 13,29 & 2,64 & 15 & 3,0 & 15,0 & 13,07 & 3,92 & 5 & 12,0 & 15,0 & 13,64 & 1,12 \\
\hline VIZ1 & 15 & 1,0 & 15,0 & 12,56 & 4,26 & 15 & 7,8 & 15,0 & 13,84 & 1,97 & 5 & 14,0 & 15,0 & 14,40 & 0,55 \\
\hline VIZ2 & 15 & 1,0 & 15,0 & 10,95 & 5,29 & 15 & 3,0 & 15,0 & 13,52 & 3,04 & 5 & 12,0 & 15,0 & 14,00 & 1,22 \\
\hline PISA & 15 & 1,0 & 15,0 & 8,03 & 5,47 & 15 & 1,0 & 16,0 & 10,35 & 5,11 & 5 & 7,4 & 14,1 & 11,84 & 2,65 \\
\hline PISB & 15 & 1,0 & 15,0 & 9,32 & 6,15 & 15 & 1,0 & 15,0 & 9,87 & 5,77 & 5 & 4,0 & 14,5 & 11,28 & 4,17 \\
\hline PISC & 15 & 1,0 & 15,0 & 9,51 & 6,08 & 15 & 1,0 & 15,0 & 10,20 & 5,61 & 5 & 9,6 & 15,0 & 13,32 & 2,45 \\
\hline PISD & 15 & 1,0 & 15,0 & 9,97 & 5,78 & 15 & 1,0 & 15,0 & 9,80 & 5,68 & 5 & 12,0 & 15,0 & 13,92 & 1,49 \\
\hline KOPA & 15 & 1,0 & 15,0 & 9,61 & 6,33 & 15 & 1,0 & 15,0 & 10,13 & 5,52 & 5 & 12,0 & 15,0 & 13,72 & 1,29 \\
\hline KOPB & 15 & 1,0 & 15,0 & 9,71 & 6,24 & 15 & 1,0 & 15,0 & 12,12 & 4,17 & 5 & 12,4 & 15,0 & 13,88 & 1,17 \\
\hline
\end{tabular}

$\mathrm{N}$ - broj ispitanika, Min - najniža vrijednost, Max - najviše vrijednost, A. S. - aritm. sredina, S. D. - stand. devijacija 
Da bismo ispitali razlike između rezultata postignutih u pojedinim komunikacijskim modalitetima, u svakom je mjerenju zasebno izračunana prosječna vrijednost varijabli pojedinog modaliteta. Prosječna vrijednost pokazala se kao dobra aproksimacija prve glavne komponente pojedinog modaliteta, što se očituje u njihovim visokim i statistički značajnim kroskorelacijama.

Tablica 4. Korelacije prosječnih vrijednosti s prvom glavnom komponentom za verbalni, gestovni i grafički modalitet

\begin{tabular}{|c|c|c|c|c|c|}
\hline & & & kVERB & kGEST & kGRAF \\
\hline \multirow{6}{*}{ 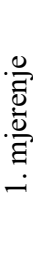 } & \multirow[t]{2}{*}{ pVERB } & Pearson $r$ & 0,998 & 0,520 & 0,085 \\
\hline & & $\mathrm{p}$ & $\mathbf{0 , 0 0 0}$ & 0,057 & 0,772 \\
\hline & \multirow[t]{2}{*}{ pGEST } & Pearson $r$ & 0,461 & 0,984 & 0,745 \\
\hline & & $\mathrm{p}$ & 0,097 & 0,000 & 0,002 \\
\hline & \multirow[t]{2}{*}{ pGRAF } & Pearson $r$ & 0,080 & 0,647 & 1,000 \\
\hline & & $\mathrm{p}$ & 0,785 & 0,012 & 0,000 \\
\hline \multirow{6}{*}{ 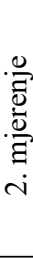 } & \multirow[t]{2}{*}{ pVERB } & Pearson $r$ & 0,985 & 0,923 & 0,520 \\
\hline & & $\mathrm{p}$ & 0,000 & 0,000 & 0,057 \\
\hline & \multirow[t]{2}{*}{ pGEST } & Pearson $r$ & 0,868 & 0,998 & 0,575 \\
\hline & & $\mathrm{p}$ & 0,000 & 0,000 & 0,032 \\
\hline & \multirow[t]{2}{*}{ pGRAF } & Pearson $r$ & 0,485 & 0,575 & 1,000 \\
\hline & & $\mathrm{p}$ & 0,079 & 0,031 & 0,000 \\
\hline \multirow{6}{*}{ 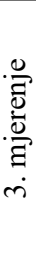 } & \multirow[t]{2}{*}{ pVERB } & Pearson $r$ & 0,876 & 0,365 & 0,296 \\
\hline & & $\mathrm{p}$ & 0,124 & 0,635 & 0,704 \\
\hline & \multirow[t]{2}{*}{ pGEST } & Pearson $r$ & 0,321 & 0,912 & $-0,430$ \\
\hline & & $\mathrm{p}$ & 0,679 & 0,088 & 0,570 \\
\hline & \multirow[t]{2}{*}{ pGRAF } & Pearson $r$ & 0,489 & $-0,066$ & 1,000 \\
\hline & & $\mathrm{p}$ & 0,511 & 0,934 & 0,000 \\
\hline
\end{tabular}

U Tablici 4. podebljano su ispisane statistički značajne kroskorelacije između prosječnih vrijednosti (pVERB, pGEST, pGRAF) i prve glavne komponente (kVERB, kGEST, kGRAF) za svaki modalitet zasebno. Sve korelacije su statistički značajne na razini $\mathrm{p}<0,01$, osim korelacija za verbalni i gestovni modalitet $u$ trećem mjerenju, iako su i one po vrijednosti vrlo visoke $\left(\mathrm{r}_{\text {verb }}=0,88\right.$ te $\left.\mathrm{r}_{\text {gest }}=0,91\right)$.

Razlike između prosječnih vrijednosti testirane su Friedmanovim testom, neparametrijskom procedurom za testiranje statistički značajnih razlika srednjih rangova malih zavisnih uzoraka, s tim da je za postupak utvrđivanja značajnosti korištena i egzaktna metoda.

Unatoč tome što statističke značajnosti razlika nisu konzistentne, evidentne su razlike u komunikacijskim postignućima ovisno o modalitetu, s tim da u oba uzorka imaju sličnu strukturu: najviše su verbalne komunikacijske sposobnosti, a najniže su grafičke komunikacijske sposobnosti.

Možemo zaključiti da je u prvom mjerenju nakon traumatskog oštećenja mozga najviše sačuvan verbalni modalitet (prosječni Porch indeks $\mathrm{M}=13,18$, odnosno $\mathrm{M}=13,48)$, slijede im gestovni modalitet koji je također relativno visok (prosječni Porch indeks $M=12,41$, odnosno $M=11,17$ ), dok grafički modalitet ima znatno smanjene rezultate (prosječni Porch indeks $M=9,67$, odnosno $M=5,03$ ).

Unatoč tome što statistička značajnost razlika nije potvrđena, razlike u komunikacijskim postignućima ovisno o modalitetu postoje. U drugom mjerenju najviše su za gestovni modalite (prosječni Porch indeks $M=13,58$, odnosno $M=13,97$ ), što znači da su pretekle verbalne koje su bile više u prvom mjerenju, slijede verbalni modaliteti (prosječni Porch indeks $M=13,25$, odnosno $M$ $=13,66$ ), a najniži je grafički modalitet (prosječni Porch indeks $M=10,73$, odnosno $M=7,93$ ).

Možemo zaključiti da u drugom mjerenju nakon traumatskog oštećenja mozga dolazi do usporavanja oporavka verbalnog modaliteta, a ubrzano se oporavljaju gestovni i grafički modalitet.

Sva tri modaliteta izjednačena su u prosječnim vrijednostima u apsolutnom smislu, a zadržana je struktura, odnosno njihov međusobni odnos iz drugog mjerenja. Nakon traumatskog oštećenja mozga, u trećem mjerenju najvišu razinu pokazuju gestovni modalitet (prosječni Porch indeks $M=14,06$ ), slijedi verbalni modalitet (prosječni Porch indeks $M=14,06$ ), a tek nešto niži su rezultati za grafički modalitet (prosječni Porch indeks $M=13,77$ ).

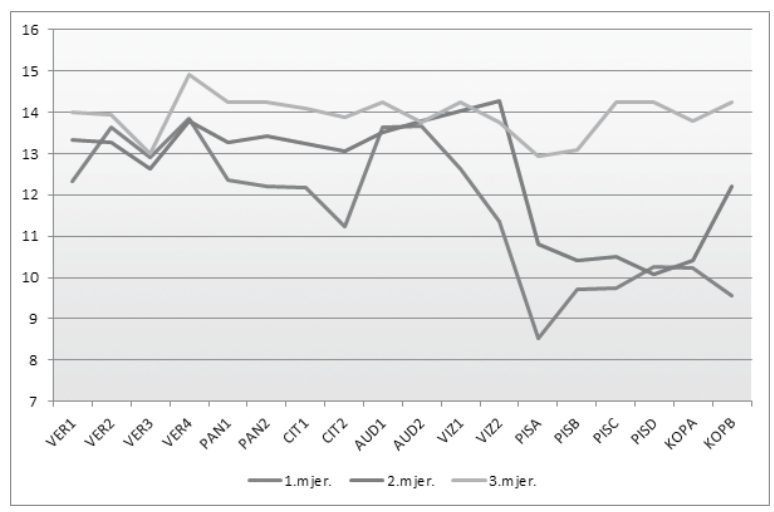

Graf 1. Prosječne vrijednosti varijabli u sva tri mjerenja 
Možemo zaključiti da se tijekom mjerenja povećava razina komunikacijskih sposobnosti u sva tri modaliteta. Međutim, rezultati statističkih analiza upućuju na pretpostavku da se nakon traumatskog oštećenja mozga komunikacijski modaliteti ne oporavljaju jednako u relativnom smislu, odnosno da je dinamika oporavka različita.

\subsection{Kvalitativna analiza razlika}

Rezultati statističkih analiza ukazuju na sljedeće:

1. U smislu apsolutnih vrijednosti, u inicijalnoj fazi komunikacijski su modaliteti različito pogođeni traumatskim oštećenjem mozga, ali se u finalnoj fazi ujednačuju, odnosno ispitanici postižu približno jednaku razinu komunikacijskih sposobnosti.

2. U smislu relativnih vrijednosti, modaliteti komunikacijskih sposobnosti ispitanika se nakon traumatskog oštećenja mozga nejednako oporavljaju - neki brže, odnosno više, a neki sporije, odnosno manje.

To upućuje na pretpostavku da je tijekom mjerenja došlo ne samo do kvantitativnih, nego i do kvalitativnih promjena u prostoru svih 18 varijabli komunikacijskih sposobnosti, kao i u prostoru varijabli pojedinih modaliteta zasebno.

U svrhu procjene da li je tijekom mjerenja došlo do kvalitativnih, odnosno strukturalnih promjena u odnosima između varijabli komunikacijskih sposobnosti ispitanika, za analizu razlika primijenjena je kvalitativna analiza u sklopu PROM procedure (Nikolić, 1997). Rezultati analize prikazani su u Tablici 5.
Iz Tablice 5. vidljivo je da je u većini mjerenja došlo do značajnih kvalitativnih, odnosno strukturnih promjena u prostoru varijabli komunikacijskih modaliteta (statistički značajne kvalitativne promjene na razini $\mathrm{p} \leq 0,05$ označene su podebljano). Jedino u verbalnom i grafičkom modalitetu između prvog i drugog mjerenja nije došlo do kvalitativnih promjena u prostoru varijabli komunikacijskih sposobnosti, gledano zasebno za svaki modalitet.

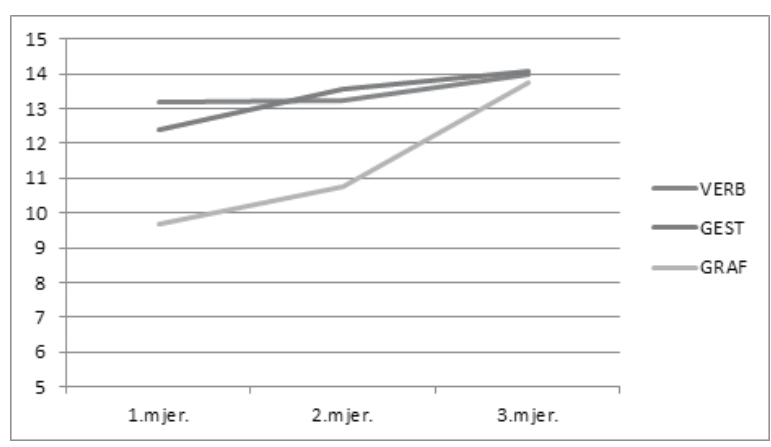

Graf 2. Prosječne vrijednosti pojedinih modaliteta $u$ sva tri mjerenja $(N=14)$

Ukupno gledajući sva tri mjerenja, do statistički značajnih razlika, odnosno statistički značajnog oporavka komunikacijskih sposobnosti došlo je u gestovnom i grafičkom modalitetu (na razini značajnosti $\mathrm{p} \leq 0,05$ ), dok u verbalnom modalitetu nije došlo do statistički značajnog oporavka.

\section{TESTIRANJE HIPOTEZE}

H 1: Postoji statistički značajna razlika na varijablama verbalni, gestovni i grafički modalitet u odnosu na prvo, drugo, i treće mjerenje.

Tablica 5. Testiranje značajnosti razlika prosječnih vrijednosti komunikacijskih sposobnosti tijekom mjerenja

\begin{tabular}{|c|c|c|c|c|c|c|c|c|c|c|}
\hline \multicolumn{6}{|c|}{ DescriptiveStatistics } & \multicolumn{5}{|c|}{ Friedman Test } \\
\hline & $\mathbf{N}$ & Mean & Std. Dev. & Min. & Max. & Mean Rank & $\mathbf{X 2}$ & df & asimpt. p & exact.p \\
\hline pVERB1 & 4 & 13,48 & 0,64 & 12,93 & 14,08 & 1,75 & 0,50 & 2 & 0,779 & 0,931 \\
\hline pVERB2 & 4 & 13,66 & 0,98 & 12,75 & 14,50 & 2,00 & & & & \\
\hline pVERB3 & 4 & 13,97 & 0,28 & 13,70 & 14,25 & 2,25 & & & & \\
\hline pGEST1 & 4 & 11,17 & 3,23 & 6,40 & 13,51 & 1,00 & 6,50 & 2 & $\mathbf{0 , 0 3 9}$ & 0,042 \\
\hline pGEST2 & 4 & 13,97 & 0,45 & 13,61 & 14,61 & 2,25 & & & & \\
\hline pGEST3 & 4 & 14,06 & 0,59 & 13,50 & 14,80 & 2,75 & & & & \\
\hline pGRAF1 & 4 & 5,03 & 5,51 & 1,00 & 12,67 & 1,25 & 6,50 & 2 & $\mathbf{0 , 0 3 9}$ & 0,042 \\
\hline pGRAF2 & 4 & 7,93 & 4,96 & 3,47 & 12,28 & 1,75 & & & & \\
\hline pGRAF3 & 4 & 13,77 & 1,03 & 12,33 & 14,77 & 3,00 & & & & \\
\hline
\end{tabular}


Tablica 6. Pregled rezultata analize razlika s obzirom na slijed mjerenja

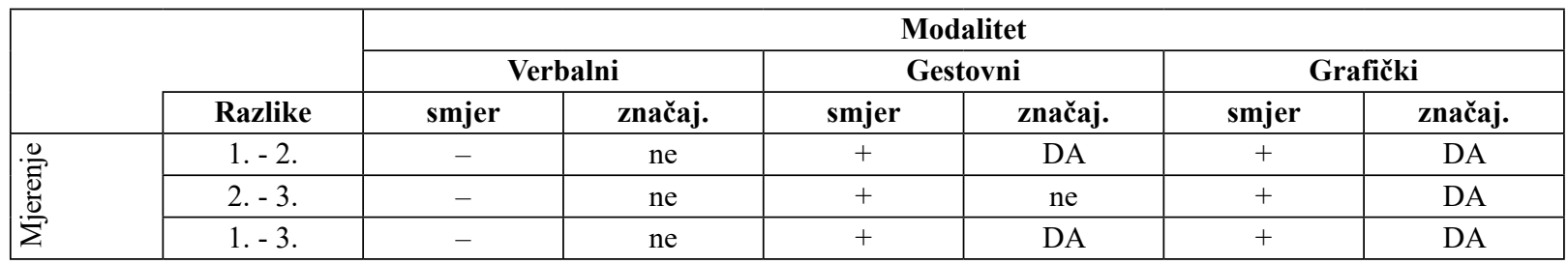

Da bismo utvrdili postoji li statistički značajan oporavak komunikacijskih sposobnosti ispitanika tijekom mjerenja u tri vremenske točke, najprije smo analizirali rezultate svih parova mjerenja, $i$ to za svaki skup varijabli komunikacijskih modaliteta zasebno.

Razlike između prvog i drugog mjerenja na varijabli verbalni modalitet u odnosu na prvo mjerenje, u drugom mjerenju ispitanici su postigli statistički značajno bolje rezultate samo na varijabli opisivanje funkcije predmeta (VER 1), u svim ostalim varijablama imenovanje predmeta (VER 2), dopunjavanje rečenica (VER 3), imitiranje naziva predmeta (VER 4) postigli su slabije rezultate, ali te negativne razlike nisu statistički značajne na razini pojedinih varijabli.

$\mathrm{Na}$ varijabli gestovni modalitet $\mathrm{u}$ odnosu prvog i drugog mjerenja, u drugom mjerenju su ispitanici postigli statistički značajno bolje rezultate na varijabli spajanje identičnih predmeta (VIZ 2), $\mathrm{s}$ tim da su razlike u varijablama čitanje naziva predmeta i smještanje kartice prema uputi (ČIT 2) i povezivanje slike predmeta s predmetom (VIZ 1) vrlo blizu statističke značajnosti. Slabiji rezultat $\mathrm{u}$ drugom mjerenju postignut je samo u varijabli pokazivanje predmeta na temelju verbalno zadane funkcije predmeta (AUD 1), ali ta razlika nije statistički značajna. Na varijabli grafički modalitet u odnosu na prvo mjerenje u drugom mjerenju ispitanici su postigli statistički značajno bolje rezultate na varijabli opisivanje funkcije predmeta (PIS A) $\mathrm{s}$ tim da je razlika na varijabli kopiranje geometrijskih oblika (KOP B) vrlo blizu statističke značajnosti. Razlike između drugog i trećeg mjerenja na varijabli verbalni modalitet $u$ odnosu na treće mjerenje nisu dobivene statistički značajne razlike, te je razlika između ova dva mjerenja negativnog smjera, što znači da su prosječne vrijednosti u trećem mjerenju niže nego u drugom. Na varijabli gestovni modalitet nije došlo do statistički značajnih kvantitativnih promjena između drugog i trećeg mjerenja, iako je razlika između ova dva mjerenja pozitivnog smjera, odnosno prosječne vrijednosti $\mathrm{u}$ trećem mjerenju nešto su više nego u drugom mjerenju. Na varijabli grafički modalitet pomoću multivarijantne analize pod komponentnim modelom došlo je do statistički značajne kvantitativne razlike između drugog i trećeg mjerenja, te da je razlika između ova dva mjerenja pozitivnog smjera, odnosno da su prosječne vrijednosti u trećem mjerenju statistički značajno više nego u drugom mjerenju. Razlike između prvog i trećeg mjerenja na verbalnom modalitetu nisu statistički značajne. Stoga možemo zaključiti da H 1: Postoji statistički značajna razlika na varijablama verbalni, gestovni i grafički modalitet u odnosu na prvo, drugo, i treće mjerenje, možemo djelomično prihvatiti.

Svi pojedinačni rezultati analize razlika s obzirom na slijed mjerenja sažeto su prikazani u Tablici 6 .

\section{ZAKLJUČAK}

Ispitanici su tijekom ispitivanja od prvog do trećeg mjerenja iskazali kontinuiran i statistički značajan oporavak gestovnih i grafičkih komunikacijskih sposobnosti. Ukupno gledajući sva tri mjerenja, do statistički značajnih razlika odnosno statistički značajnog oporavka komunikacijskih sposobnosti došlo je u gestovnom i grafičkom modalitetu (na razini značajnosti $\mathrm{p} \leq 0,05$ ), dok u verbalnom modalitetu nije došlo do statistički značajnog oporavka.

Komunikacijske teškoće kod osoba s traumatskim oštećenjem mozga jako su različite, budući da su lezije difuzne, uzrokovane različitim vrstama udaraca, a ne smijemo zanemariti ni status pacijenta prije ozljede. Tu ponajprije mislimo na dob, cerebralnu dominantnost, obrazovanje i socio-ekonomski status.

Ovisno o mjestu i težini traumatskog oštećenja mozga, u komunikaciji se mogu javiti teškoće u 
jeziku, i to na svim jezičnim sastavnicama - leksiku, semantici, sintaksi i pragmatici, kao i teškoće u govoru, od kojih je najčešća i ima najduži tijek oporavka - dizartrija.

Komunikacijske teškoće nakon traumatske ozljede mozga vrlo su širokog spektra. Osim jezika i govora svakako treba obratiti pažnju i na kognitivne aspekte: pamćenje, učenje novih sadržaja i pažnju.

Prema ASHA-i, "Kognitivno-komunikacijske teškoće možemo definirati kao teškoće u komunikaciji i kognitivnom funkcioniranju. Komunikacija uključuje slušanje, govorenje, geste, čitanje i pisanje u svim područjima jezika (fonologije, morfologije, sintakse, semantike i pragmatike). Kognitivne teškoće uključuju pažnju, pamćenje, organizaciju, izvršne funkcije i teškoće u ponašanju, socijalnu interakciju, dnevne aktivnosti, učenje i obrazovanje". Zbog neujednačene terminologije koja je vladala između jezika i kognitivnih teškoća koju su različiti autori koristili, American SpeechLanguage-Hearing Association (ASHA) je 2004. godine za složenost poteškoća koje sa javljaju nakon traumatske ozljede mozga predložila termin Kognitivno-komunikacijske teškoće.

Veliki problem u Hrvatskoj predstavlja to što nema standardiziranih testova pomoću kojih bismo dijagnosticirali kognitivno-komunikacijske teškoće nakon traumatskog oštećenja mozga, a koji bi u jednom testu ujedinjavali više testova i pokrivali široko područje komunikacije i kognicije.

Na temelju dobivenih rezultata naših ispitanika možemo zaključiti da verbalni modalitet pokazuje najmanji stupanj oporavka, odnosno najsporije se oporavlja jer se najčešće radi o dizartriji, teškoći govora koju karakteriziraju teškoće na respiratornom, fonacijskom, artikulacijskom i / ili na rezonantnom planu (Murdoch, Theodors, 2001). Pritom treba uzeti u obzir da je u inicijalnom mjerenju ovaj modalitet najmanje pogođen traumatskim oštećenjem mozga.
Gestovni je modalitet u inicijalnoj fazi nešto više pogođen traumom nego verbalni, ali se vrlo brzo oporavlja, što možemo reći da je posljedica ranih rehabilitacijskih tretmana i vremena provedenog u terapiji. Već u drugom mjerenju ispitanici pokazuju bolje rezultate na gestovnom, nego na verbalnom modalitetu. Nakon toga oporavak više nije tako izrazit.

Sve osobe s doživljenom traumatskom ozljedom mozga imaju posljedično izraženo parezu ili plegiju ekstremiteta, uz spazme i kontrakture, što svakako pridonosi lošim rezultatima u grafičkom modalitetu, tj. otežanoj i nespretnoj grafomotorici, pa sukladno i s tim i najlošijim rezultatima upravo na grafičkom modalitetu.

Oporavku grafičkog, a naravno i gestovnog pa i verbalnog modaliteta pridonosi, osim rane i pravovremene rehabilitacije, svakako, interdisciplinarni pristup koji je od izuzetne važnosti, a podrazumijeva suradnju članova tima, međusobnu komunikaciju i odgovornost (Brookshire, 2007).

Kao noviji oblik timskog rada navodi se i transdisciplinarni pristup u kojima se potiče ne samo komunikacija, nego i opće poboljšanje psihofizičkog zdravlja. (Hoffman, 1990, Reilly, 2001; Bakran, 2012).

Rezultati dobiveni u ovom ispitivanju doprinose logopedskoj rehabilitaciji nakon traumatskog oštećenja mozga. Ukazuju s kojim se komunikacijskim modalitetima može započeti rehabilitacijski tretman, odmah po stabilnosti tjelesnih funkcija, i kod kojih modaliteta možemo očekivati najveći stupanj oporavka, te za koje je modalitete potrebna dugotrajnija kontinuirana logopedska rehabilitacija.

Traumatsko oštećenje mozga utječe na poimanje sebe, način razmišljanja i osjećaje osobe. Posljedice koje se javljaju nakon traumatskog oštećenja mozga ne mogu se predvidjeti. Efekti traumatskog oštećenja mozga složeni su i raznoliki, a ovise o uzroku, lokaciji i težini oštećenja svakog pojedinca. 


\section{LITERATURA:}

Adamovich, B. L. B.,(2001): Traumatic brain injury. U La Pointe, L. L. (ur) (2001) : Aphasia and Related Neurogenic Disorders. Theime, New York - Stuttgart.

Bakran Ž.,(2012): Modeli timske suradnje u fizikalnoj i rehabilitacijskoj medicini,Fizikalna i rehabilitacijska medicina,Hrvatsko društvo za fizikalnu i rehabilitacijsku medicinu pri HLZ, 83-87.

Brookshire, R. H.,(2007): Introduction to Neurogenic Communication Disorders,Seventh Edition,Department of Communication Sciences and Disorders,University of Minnesota.

Code, C., McDonald, S., Togher, L. (1999): Comunication disorders following traumatic brain injury. Psychology Press, Glouchester.

Cooper P., (1993): Head injury.3 rd ed. Williams and Wilkins, Baltimore.

Davis G.Albyn,(2007):Aphasiology,Disorders and clinical practice,Second edition,University of Massachusetts.

Graham,D. I. \& Gennarelli, T. A. (2000): Pathology of brain damage after head injury. In P.R.Cooper \& J.G.Golfinos (Eds),Head injury (4th ed., pp. 133-153) New York:McGraw - Hill.

Graham D.I., McIntosh T.K., Maxwell W.L., et al (2000): Recent advances in neurotrauma. J Neuropath Exp Neurol,59:641-651.

Halpern H., Goldfarb R.( 2012): Language and Motor Speech Disorders in Adults, Third edition.

Hegde M.N.(2006): A Coursebook on Aphasia and Other Neurogenic Lenguage Disorders, Third edition.

Murdoch, B.E., Theodoros,D.G.(2001): Traumatic brain injury: Associted speech, Lenguage and swallowing disorders. Albany,NY: Singular Thomson Learning.

Porch, B. E. (1981) : Porch indeks of comunicative ability. The Riverside Publishing Company, Chicago.

Yorkston,K.M. \& Beukelman,D.R.(1981): Assessment of intelligibility of dysarthric speech.Austin, TX: Pro-Ed.

Ylvisaker, M. , Szekeres, S. F. , Fenney, T. : Comunication disorders associated with traumatic brain injury. U : Chapey, R. (ur) (2001) : Language intervention strategies in aphasia and related neurogenic comunication disorders. Lippincott Williams and Wilkins, Baltimore.

Mrežni izvori:

http://www.asha.org/public/speech/disorders/TBI 17.05.2016.

http://www.braininjury.com/injured.html 09.10.2016.

\section{ASSESSMENT OF COMMUNICATION ABILITIES IN PERSONS WITH TRAUMATIC BRAIN INJURIES DURING REHABILITATION}

\footnotetext{
Abstract: Communication abilities can be affected differently by traumatic brain injury because of differences in the types of impact and the types and severity of brain lesions. The present study used a Croatian version of the Porch Index of Communicative Ability (Porch, 1981) to assess verbal, gesticular and graphic communication abilities in persons with traumatic brain injuries (in 14 men and women aged 21-62 years). Assessments were performed three times at intervals of 3 months during rehabilitation at a specialized clinic in Krapinske Toplice. Data were analyzed using uni- and multivariate analyses. The Friedman nonparametric test was used to assess the significance of differences between small dependent samples. PROM software (Nikolić, 1997) was used to compare quantitative and qualitative changes between two time points within one sample. The results indicate that rehabilitation was more effective for gesticular abilities, less effective for verbal abilities, and least effective for graphic abilities, reflecting the presence of pareses and plegias of extremities. The results point to the importance of targeting certain communication abilities during early rehabilitation after brain injury.
}

Key words: traumatic brain injury, communications difficulties, Porch Index of Communiciative Abitlity. 